\title{
SUSTAINABLE FUNCTIONING OF THE ENERGY SECTOR IN EMERGING COUNTRIES OF THE EASTERN EUROPE
}

\author{
Ecaterina RESNIOVA ${ }^{1 *}$, Tatiana PONOMARENKO ${ }^{2}$ \\ ${ }^{1}$ Saint-Petersburg Mining University, Saint-Petersburg, Russia; reshniovakate@gmail.com, \\ ORCID: 0000-0002-7685-2694 \\ ${ }^{2}$ Saint-Petersburg Mining University, Saint-Petersburg, Russia; stvmail@mail.ru; \\ ORCID: 0000-0001-5047-2880 \\ * Correspondence author
}

Purpose: This article presents a comparative analysis of the energy sectors of Romania, Poland and the Republic of Moldova.

Design/methodology/approach: The analysis of statistical data on energy efficiency is used, as well as identifies factors of sustainable energy development.

Findings: The study concludes on the factors and prospects of sustainable functioning of the energy sector of the presented countries.

Originality/value: The countries of the European Union are energetically developed to a different degree: among them there are countries that have their own energy resources and countries with very scarce energy resources. Modern requirements for energy efficiency determine the necessity for the development of "green energy".

Keywords: energy sector, sustainable functioning, energy of the European Union, "green" energy, energy efficiency.

Category of the paper: Research paper.

\section{Introduction}

The sustainable functioning of the energy sector is a priority for many developing countries of the European Union. Under the term of sustainability of the energy sector, this paper refers to the uninterrupted functioning of the energy industry, mainly in the development of production of its own energy resources, the established scheme of their transportation and delivery, functioning transport and distribution grids of electricity and heat, the supply of full volume of electricity and heat to consumers. An important factor in the sustainability of the energy sector is the possibility of diversifying energy resources and the production of heat and electricity by sources. The main direction of diversification in the European Union is the 
development of "green" energy, which is also associated with the aggravation of environmental problems connected with the traditional methods of energy generation.

Sustainable functioning of the energy sector is an actual goal for the countries of the European Union, which allows for forming energy security.

Since many EU countries are energy importers, the political context of relations with energy suppliers and transit regions becomes an important factor in ensuring energy sustainability.

Problems of energy sustainability and energy supply are particularly relevant for EU countries, as there are the following reasons for this:

1. In terms of fuel consumption, the EU is in the third place, after the USA and China. The North Sea is an important source of energy for the EU. At the current rate, energy production may be sufficient for the next eight years, which could lead to the EU becoming even more dependent on foreign energy supplies and affect the energy security of EU countries.

2. As a result of active integration processes and expansion, there is also an increase in energy demand in the EU. The main reason is that most of the Eastern European countries, in the past, were part of the energy supply system of the USSR, which creates difficulties in creating a European energy supply system. If one compares the power consumption in the $20^{\text {th }}$ and the $21^{\text {st }}$ century, the difference equals to an increase by $40 \%$.

The EU's energy sustainability will depend, to a large extent, on the ability of member states to overcome differences in solution of three main challenges:

1. building strong partnerships with energy producers and transit countries,

2. use and active development of "green energy",

3. effective functioning of the internal system to ensure reliable and safe energy supply to the EU countries.

The purpose of this article is to conduct a comparative analysis of the energy sectors of Romania, Poland and the Republic of Moldova, in order to identify priority factors for sustainable development of the energy sector of each country.

The main objectives of this paper are as follows:

1. Analysis of the current state of the energy sector in Romania, Poland and Moldova.

2. Assessment of the existing and possible diversification of energy resources and energy generation in each country.

3. Carrying out a comparative characteristic of the energy sector of the selected countries.

4. Identification of the factors of sustainable functioning of the energy sector of the countries. 


\section{Research methods}

The article uses a collection of statistical data of country energy sectors, as well as comparative and logical analyses.

\section{Results}

Romania, Poland and the Republic of Moldova have common features and differences in the economy and energy sector. The main energy operation indicators of these countries are presented in Table 1.

\section{Table 1.}

Comparative characteristics of main indicators in energy sectors of Romania, Poland and the Republic of Moldova

\begin{tabular}{|c|c|c|c|}
\hline Name of indicator & Romania & Poland & $\begin{array}{l}\text { Republic of } \\
\text { Moldova }\end{array}$ \\
\hline $\begin{array}{l}\text { Total production of primary energy, quadrillion BTU (British } \\
\text { thermal units) in } 2016\end{array}$ & 1.06 & 2.63 & 0.01 \\
\hline $\begin{array}{l}\text { Total consumption of primary energy, quadrillion BTU (British } \\
\text { thermal units) in } 2016\end{array}$ & 1.37 & 4.13 & 0.13 \\
\hline $\begin{array}{l}\text { Total CO2 emissions from energy consumption, million metric tons } \\
\text { in } 2016\end{array}$ & 71.68 & 307.4 & 7.61 \\
\hline $\begin{array}{l}\text { Energy intensity level of primary energy, MJ per dollar of GDP in } \\
2015\end{array}$ & 4 & 4.14 & 8.39 \\
\hline Import of electricity, billion kilowatt-hours in 2016 & 4.18 & 14.02 & 0.2 \\
\hline Export of electricity, billion kilowatt-hours in 2016 & 9.19 & 12.02 & 0.00 \\
\hline $\begin{array}{l}\text { *Energy consumption from fossil fuels, \% of energy consumption, } \\
\text { in } 2015\end{array}$ & 72.5 & 90.3 & 88.7 \\
\hline $\begin{array}{l}\text { **Alternative and nuclear energy, \% of energy consumption, } \\
\text { in } 2015\end{array}$ & 14.5 & 1.1 & 0.8 \\
\hline $\begin{array}{l}\text { Generation of electricity from the sun, tides and waves, billion } \\
\text { kilowatt-hours, in } 2016\end{array}$ & 1.82 & 0.13 & 0.02 \\
\hline Hydropower generation, billion kilowatt-hours, in 2016 & 17.85 & 2.12 & 0.23 \\
\hline Wind power generation, billion kilowatt-hours, in 2016 & 6.59 & 12.28 & 0.03 \\
\hline $\begin{array}{l}\text { Power generation from biomass and waste, billion kilowatt-hours, } \\
\text { in } 2016\end{array}$ & 0.53 & 8.17 & 0.01 \\
\hline Nuclear power generation, billion kilowatt-hours, in 2016 & 10.39 & 0 & 0 \\
\hline $\begin{array}{l}\text { Amount of kWh available on the average monthly income of } \\
\text { residents, in } 2018\end{array}$ & $4,127.2$ & $5,011.3$ & $2,379.5$ \\
\hline The cost of electricity for the population, euro per $\mathrm{kW} / \mathrm{h}$, in 2018 & 0.13 & 0.15 & 0.11 \\
\hline
\end{tabular}

*Fossil fuels include coal, oil, non-petroleum products and natural gas products.

**Carbon-free energy that does not produce carbon dioxide during production. It includes hydropower, nuclear, hydrothermal and solar energy.

Note: Compiled by the author using information from global data source - World and regional statistics. 


\title{
4. Discussion
}

The presented data shows that the Republic of Moldova falls behind from Romania and Poland in terms of the dynamic energy sector. Therefore, it is interesting to study the energy experience of these countries.

The energy sectors in Romania and Poland differ significantly.

Romania's accession to the European Union (hereinafter the EU) was the main impulse for the restructuring of the vertically integrated state electricity sector. The free electricity market was officially opened on July 1, 2007, and allowed independent producers to produce and sell electricity on their own.

The structure of power generation in Romania is shown in Figure 1.

\section{The structure of power generation in Romania}

(2019)

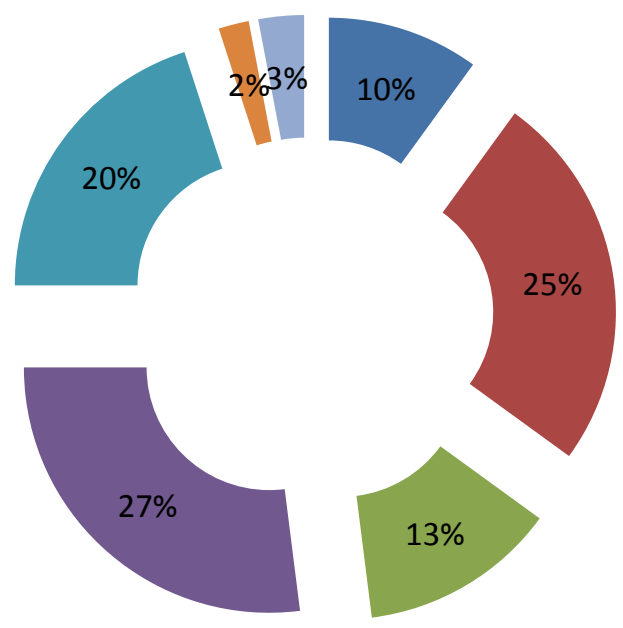

\author{
Wind turbine \\ - Coal-fired power plants \\ - TPP on gas and fuel oil \\ - Hydropower \\ nuclear power \\ Biomass \\ - Solar power
}

Figure 1. Structure of power generation in Romania (2019). Adapted from the Official website of the Romanian transmission system operator.

Romania has the largest oil and gas reserves in the Central Europe. But, due to the fact that the reserves of "black gold" in the recent decades have depleted, the production falls; local energy companies are in search of new sources of raw materials and ways of attracting investors. The governmental authorities consider the nuclear industry to be one of the main directions of the energy development. Currently, two power units of NPP "Cernavoda" operate in Romania, and the commissioning of the third and fourth blocks is in the nearest plans.

Renewable energy sources have undiscovered potential, mainly dominated by hydropower and wind energy. Upon accession to the EU, Romania has carried out a number of reforms in the field of energy policy, in particular the "Law on energy efficiency", which provides, that all new residential and public buildings should be audited and have an energy efficiency certificate. Romania has special procurement tariffs and a system of green certificates for electricity produced from renewable energy sources. 
In accordance with the statistical report released by IRENA (International Renewable Energy Agency), in 2017, the total installed capacity of renewable energy facilities in Romania amounted to 6,349 MW in 2007, 6,791 MW in 2010 and 11,316 MW in 2016 (International Renewable Energy Agency, 2016).

Thus, Romania has a diversified structure of energy sources, great opportunities for renewable energy development, which helps to reduce energy failures, strengthen energy security and increase the stability of the country's energy system.

The Polish power system has a different generation structure and is practically not diversified. The structure of the installed capacity of the Polish power system is shown in Figure 2.

\section{The structure of power generation in Poland (2019)}

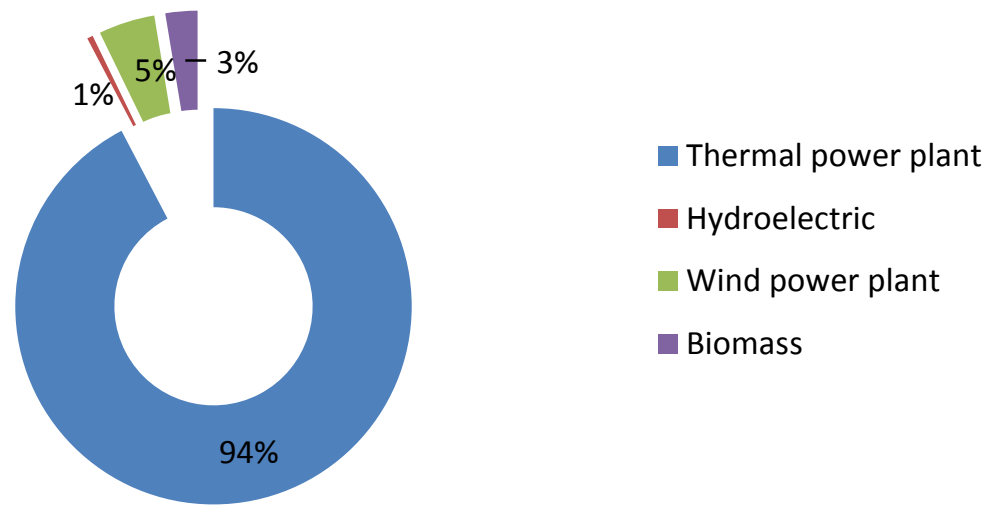

Figure 2. The structure of power generation in Poland in 2019. Adapted from the Official website of Polish electric power system.

In the structure of thermal power plants, $97 \%$ are coal-fired stations, and only $3 \%$ of the stations operate using gas. The coal industry has been widely developed. Three large Polish companies - Węglokoks, Kompania Węglowa and Jastrzębska Spółka Węglowa - produce about 100 million tons of coal per year. In this regard, coal is an inexpensive resource to provide the country with power $-50 \%$ of the primary energy and about $85 \%$ of electricity in the country.

In Poland, the state owns most of the mining enterprises; therefore, it is interested in the economic results and energy security of the country, as well as in the use of its own energy sources, but it is limited by the EU legislation, which advocates the closure of coal mines in Poland and financially supports the modernization of energy infrastructure and the development of alternative energy sources (Dzhonek-Kovalska et al., 2018).

The main investors in the Polish energy sector are the French EDF company, which owns thermal power plants in Krakow, Gdansk, Wroclaw, and Engie, whose total capacity of energy it facilities is $4.8 \mathrm{GW}$. 
The Czech Republic and Slovakia are the key export destinations for Poland.

There are no operating nuclear power plants in Poland. The construction of the "Żarnowiec" nuclear power plant began in 1983 and ended in 1990. It was planned to build a nuclear power plant with a capacity of $1.86 \mathrm{GW}$, but the construction of nuclear power plant "Żarnowiec" is suspended for three decades now. The population of Poland has a negative attitude towards this project, due to the large-scale disaster at the "Chernobyl" nuclear power plant. As for now, the NPP "Żarnowiec" is not suitable for use.

The total installed capacity of renewable energy facilities in Poland was 1,301 MW in 2007, 2,178 MW in 2010 and 8,030 MW in 2016 according to the statistical report released by IRENA in 2017 (International Renewable Energy Agency, 2017).

The EU membership facilitates the development of renewable energy in Poland, introducing requirements to reduce $\mathrm{CO} 2$ emissions and plans to achieve the share of renewable energy in the energy sector of at least $50 \%$ by 2050 . Since the entry into force of the carbon dioxide emission quotas from 2019, companies have to either pay for the emissions or install expensive capture filters - in any case, coal-fired power plants become unprofitable.

In Poland, like in Romania, the system of renewable energy Certificates has been introduced, which stimulates the production of renewable energy. The main difference is that, in Poland, the color marking of certificates is different: green, yellow, red, purple and brown, depending on the type of "green" energy generation technology.

There are incentives for RES development: the EU membership, which is clearly aimed at environmentally friendly types of generation, reduction of energy production at coal-fired power plants and, perhaps, the eventual possibility of building a nuclear power plant.

Thus, Poland has its own coal reserves, a non-diversified energy sector, is limited by the EU in the use of coal and is forced to develop "green" energy.

The Republic of Moldova has very few energy resources, including solid fuel, oil and gas, therefore it is more energy-dependent. The share of imports reaches about $74 \%$ of total energy consumption. Energy imports come mainly from Transnistria and Ukraine. At the same time, the level of energy intensity in Moldova is relatively high. The efficiency of energy conversion is at a low level, which is associated with outdated production technologies, deterioration of equipment and high electrical and heat losses in the systems. 


\title{
The structure of power generation in Moldova
}

\section{(2018)}

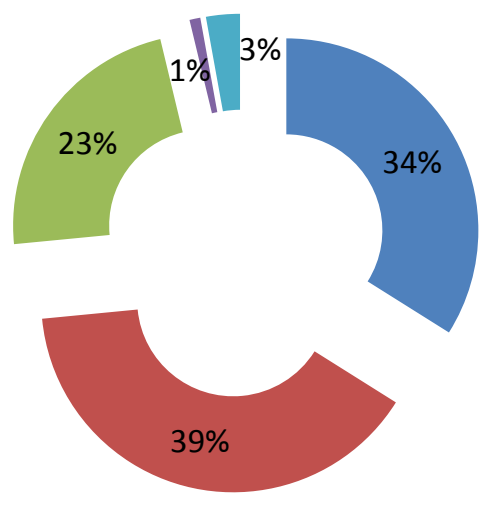

\author{
Gas-fired power plants \\ Power plants operating on \\ fuel oil \\ Coal-fired power plants \\ Hydropower plant \\ - Power plants operating on
} RES

Figure 3. The structure of power generation in Moldova in 2018. Adapted from the Official website of the operator of the transmission system of the Republic of Moldova.

The main sources of electricity in the Republic of Moldova are thermal power plants, which operate on gas, coal and fuel oil. The total installed capacity is 2,999 MW (Figure 3). The rest of the electricity is generated by hydroelectric power plants, with installed capacity of $64 \mathrm{MW}$, and RES.

The scarcity of energy resources, favorable geographical conditions and possible integration with the European Energy System are the factors that move forward the development of RES in the Republic of Moldova. The possibility of development of "green" energy is great. A study by IRENA showed that the Republic of Moldova has an extensive technical potential for renewable energy, estimated at more than $21 \mathrm{GW}$. This capacity is 10 times higher than the current installed capacity of all power plants in the country (International Renewable Energy Agency, 2017). Since March 2018, a new "Law on the promotion of renewable energy" has come into force, which provides a mechanism to stimulate investors. According to some experts, if the investment is sufficient, the Republic of Moldova will be able to become an energy independent state in 30-40 years.

One of the promising directions of solving the energy crisis is the development of cooperation between the energy systems of Moldova and Romania. This requires modernization and reconstruction works in order to generate capacities and networks, as well as expansion of the power grid and increase of voltage, reduction of losses in transport and distribution grids and the increase of share of electricity generated from renewable energy sources. 


\section{Conslusions}

1. Analysis of Romania's energy sector showed that the country is developing various types of energy production, which, in turn, has a positive impact on the sustainability of the energy sector and the economy as a whole. Alternative energy sources are dominated by hydropower and wind power, also more solar and biomass power plants are planned.

2. The energy sector of Poland is at the stage of changes: the operation of coal-fired power plants is becoming unprofitable. In this regard, there is a necessity for the introduction of new energy generation facilities and the active development of RES.

3. The Republic of Moldova has been experiencing a shortage of electricity for more than 25 years. The country has a great potential for the development of RES and the possibility of interaction of the energy sector with the EU, which will allow the Republic of Moldova to get out of the crisis.

4. The factors of sustainable development of the energy sector in developing economies are:

- Availability of own energy resources.

- Diversification of energy sources.

- Development of renewable energy sources.

- Modernized energy infrastructure.

- Reliable legislation in energy efficiency, energy security and "green" energy in emerging countries.

\section{References}

1. Jonek-Kovalska, I., Ponomarenko, T.V., Marinina, O.M. (2018). Problems of interaction with stakeholders during implementation of long term mining projects. Journal of Mining Institute, 232, 428-437.

2. Kaveshnikov, N.Y. (2013). Development of the External Energy Policy of the European Union. Vestnik MGIMO, 4, 82-91.

3. Kaveshnikov, N.Y. (2014). Renewable energy in the EU: changing priorities. World economy and international relations, 12, 70-81.

4. Official website of the International renewable energy Agency. Retrieved from: http://renewnews.ru/irena/, 10.07.2019.

5. Official website of the National Institute of statistics of Romania. Retrieved from: http://www.insse.ro/cms/, 10.07.2019. 
6. Official website of the operator of the transmission system of the Republic of Moldova. Available online http://www.moldelectrica.md, 28.04.2019.

7. Official website of the Polish electric power system. Available online https://www.pse.pl/home, 15.07.2019.

8. Official website of the Romanian transmission system operator. Retrieved from: http://www.transelectrica.ro/home, 07.07.2019.

9. Seliverstov, S.S., Gudkov I.V. (2014). Energy law of the European Union. Moscow: Aspekt Press, 288.

10. World and regional statistics [Electronic resource]. Available online https://knoema.ru, 15.07.2019.

11. World Energy Trilemma: Time to get real - the agenda for change [Electronic resource]. World Energy Council. http://www.worldenergy.org, 01.07.2019.

12. Zhiznin, S.Z. (2010). Energy in contemporary world and international energy diplomacy. Baltiiskii region, 1, 5-17. 